\title{
Seizing opportunities as they come
}

\author{
Tracie Rindfield, SRS, LAT, Surgical Research Consultant, Lawrence, MI
}

\begin{abstract}
Ms. Rindfield traces her career path in surgical services and shares what inspires her about biomedical research.
\end{abstract}

\section{How did you first become interested in the field of laboratory animal science? Honestly, I had no idea what laboratory animal science was until I applied for an animal care position in the summer of 1995, not realizing this was the beginning of a lifelong passion. But I've always been drawn to science: at a young age, my mother gave me a set of medical dictionaries, and I would sit and look through them, studying the pictures and the words. When I was 19 years old, my dad had a heart attack. It was both scary and intriguing to me; I was determined to understand what had happened to him.}

\section{How did you manage to work your way up from your first position?}

I first worked in the area of small animal toxicology, and I loved it. Rats and mice were, and still are, my favorite species; they have the best nature. In the spring of 1997, an opportunity came about when the clinical medicine surgical services department required help with the increasing number of surgical studies they were conducting. I was able to cross train in the surgical services area, helping with placement of vascular access ports; anesthesia; and preoperative, perioperative and postoperative care. After the first time I scrubbed in and helped to place access ports, I was hooked on surgery. That winter I transferred to the clinical medicine and surgical services department, where I was able to function as a technician, a supervisor and a surgeon. These experiences made me a better scientist and taught me many technical and managerial skills. One of the best parts was working side by side with the veterinarians and learning so much from them about anatomy and physiology.

From 2004 until 2013, I was responsible for performing both routine and complex surgical procedures. I worked with many different species and gained a vast amount of surgical knowledge. I enjoyed working with sponsors and learning the story behind the device or drug that was being tested.

\section{What inspired your interest in animal surgery?}

I've always had a curious mind. When I was a kid, I wanted to open my toys, look at their insides and put them back together. The game Operation was a favorite of mine, and I got to the point that I would play lefthanded to challenge myself. Seeing organs functioning inside of a live body is amazing; being able to place a device within those functioning organs is even more amazing.

During early 2000, I got a chance to help with research on the sirolimus-eluting coronary stent. Our data was used as the basis of clinical trials for the device, which was later approved by the FDA. This is significant to me personally because my dad has 11 stents, the majority of which are sirolimus-eluting stents. Medical research saved his life! And now my kids get to enjoy their granddad.

\section{You have accomplished a great deal! What is next for you?}

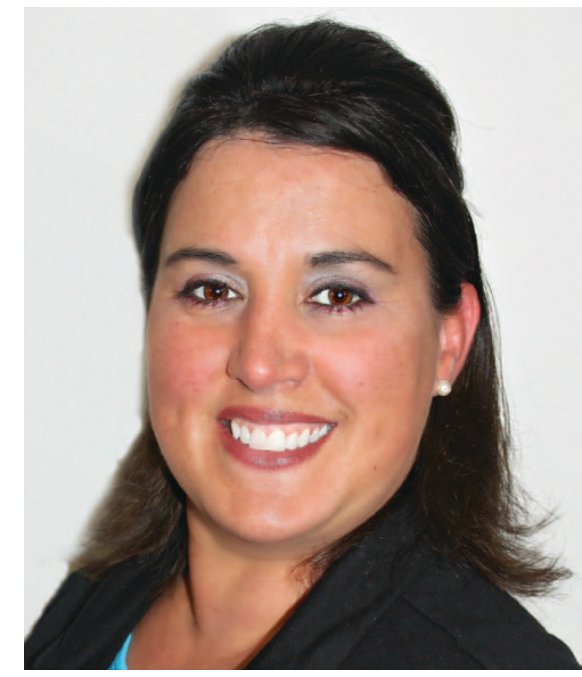

Consulting and teaching is what's next for me. After working in biomedical research for nearly 20 years, I realized my passion could become a business. I'm now the CEO of Rindfield Consulting. As a surgical research consultant, I'm able to advise biomedical surgical clients on surgical models; preoperative, perioperative and postoperative care; and training technical staff. I'm also the treasurer of the Academy of Surgical Research, and I look forward to continuing to be involved with this organization. And most importantly, I look forward to spending more time with my family.

\section{What is the most valuable thing that you learned during your career?}

Everything happens for a reason: the position you're in, the advice you receive, the opportunities you get, the people you meet, the hardships you endure and the time it takes to make it all happen. Take time to appreciate everything, good or bad. The motto I've always lived by is a quote from Thomas Edison: "Opportunity is missed by most people because it's dressed in overalls and looks like work." 